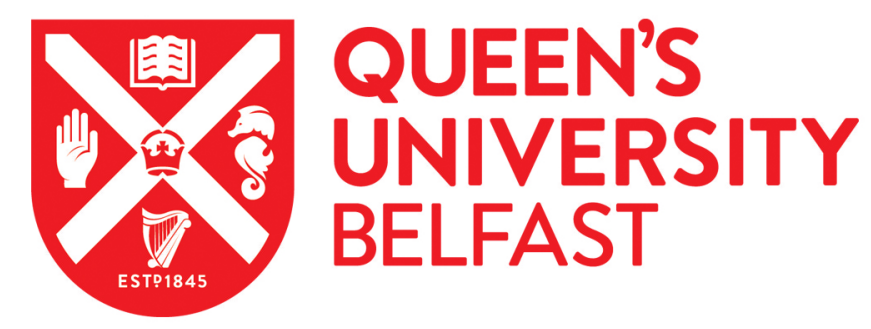

\title{
Arbuscular mycorrhizal status of spring ephemerals in the desert ecosystem of Junggar Basin, China
}

Shi, Z. Y., Feng, G., Christie, P., \& Li, X. L. (2006). Arbuscular mycorrhizal status of spring ephemerals in the desert ecosystem of Junggar Basin, China. Mycorrhiza, 16(4), 269-275. https://doi.org/10.1007/s00572-006$0041-1$

Published in:

Mycorrhiza

Queen's University Belfast - Research Portal:

Link to publication record in Queen's University Belfast Research Portal

\section{General rights}

Copyright for the publications made accessible via the Queen's University Belfast Research Portal is retained by the author(s) and / or other copyright owners and it is a condition of accessing these publications that users recognise and abide by the legal requirements associated with these rights.

Take down policy

The Research Portal is Queen's institutional repository that provides access to Queen's research output. Every effort has been made to ensure that content in the Research Portal does not infringe any person's rights, or applicable UK laws. If you discover content in the Research Portal that you believe breaches copyright or violates any law, please contact openaccess@qub.ac.uk. 


\section{Arbuscular mycorrhizal status of spring ephemerals in the desert ecosystem of Junggar Basin, China}

Received: 5 July 2005 / Accepted: 22 December 2005 / Published online: 28 March 2006

(C) Springer-Verlag 2006

\begin{abstract}
A survey was made of the arbuscular mycorrhizal (AM) status of 73 spring ephemeral plant species that grow in the desert ecosystem of Junggar Basin, northwest China. The proportion of AM colonization ranged from 7 to $73 \%$ with a mean value of $30 \%$. A total of 65 plant species studied were AM with coils/arbuscules or vesicles and the remaining eight species were possibly AM with no coils/arbuscules or vesicles but with fungal mycelia in the root cortex. AM fungal spores were isolated from rhizosphere samples of all 73 plant species and identified. The mean spore density was 22 per $20 \mathrm{ml}$ of air-dried soil, ranging from 0 to 120 . Colonization and spore density of perennials were slightly higher than of annuals and varied among different plant families. A total of 603 AM fungal spore (or sporocarp) specimens were isolated belonging to six genera, Acaulospora, Archaeopora, Entrophospora, Glomus, Paraglomus, and Scutellospora; Glomus was the dominant genus. We conclude that spring ephemerals may be highly dependent on AM associations for survival in the very infertile and arid soils of this desert ecosystem.
\end{abstract}

Electronic Supplementary Material Supplementary material is available for this article at http://dx.doi.org/10.1007/s00572-0060041-1

Z. Y. Shi · G. Feng $(\bowtie) \cdot$ P. Christie $\cdot$ X. L. Li College of Natural Resources and Environmental Sciences, China Agricultural University,

2 Yuan Min Yuan West Road, Haidian District,

Beijing 100094, People's Republic of China

e-mail: fenggu@cau.edu.cn

Tel.: +86-10-62733885

Fax: +86-10-62731016

G. Feng

Xinjiang Institute of Ecology and Geography,

Chinese Academy of Sciences,

Urumqi 830000, People's Republic of China

P. Christie

Agricultural and Environmental Science Department,

Queen's University Belfast,

Newforge Lane,

Belfast BT9 PX, UK
Keywords Arbuscular mycorrhiza - Spring ephemeral plants · Root colonization - Spore density ·

Desert ecosystem

\section{Introduction}

We use the term "ephemerals" here to include both annual and perennial species with a very short period of growth aboveground. The aboveground parts of the perennial ephemerals usually die at the end of the growing period but the belowground structures (bulbs, corms, or tubers) enter a period of dormancy until the subsequent time of sprouting. The dominant plant species in Gurbantunggut Desert in the Junggar Basin, northwest China, the ephemerals, grow for a short period each year from early spring (late March) to early summer (late May). These plants can take advantage of the favorable soil moisture conditions and warm temperatures in spring to grow rapidly to the flowering stage within about 2 months before arid conditions return (Zhang 2002a). In April, May, and early June, the mean cover of spring ephemerals reaches $13.9,40.2$, and $14.1 \%$, respectively, with a mean plant height of 10-20 cm (Wang et al. 2003). The plants that play a very important role in the stabilization of sand dunes are pioneer species during the rehabilitation of degraded desert areas (Wang et al. 2003) and can reduce the frequency of occurrence and intensity of sandstorms.

In natural ecosystems, the majority of higher plant roots are associated with arbuscular mycorrhizal (AM) fungi belonging to the phylum Glomeromycota (Schüßler et al. 2001). Disturbance of the vegetation cover is the first visible indication of a desertification process, but damage to physical, chemical, and biological soil properties are known to occur concomitantly (Requena et al. 2001). With regard to biological components, land degradation is usually associated with reduction in belowground microbial diversity and/or activities governing the biogeochemical cycles of the major plant nutrients (Kennedy and Smith 1995). In particular, desertification reduces the diversity and inoculum potential of AM fungi (Jasper et al. 1991). As 
a result, arbuscular mycorrhizas of desert plants have been the subject of a number of studies in recent years (O'Connor et al. 2001; Titus et al. 2002; Collier et al. 2003; Ferrol et al. 2004), but to our knowledge there are no detailed published studies of the incidence of AM in spring ephemerals in desert ecosystems. We therefore conducted a systematic survey of the biodiversity of AM fungi and AM colonization of spring ephemeral plant communities in the Junggar Basin from March to July 2004 to understand the AM status of these important plants.

\section{Materials and methods}

Geography of the study area

The Junggar Basin $\left(34^{\circ} 09^{\prime}-49^{\circ} 08^{\prime} \mathrm{N}, 73^{\circ} 25^{\prime}-96^{\circ} 24^{\prime} \mathrm{E}\right)$ forms a triangle between the Altai and Tianshan mountain ranges. It extends $1,100 \mathrm{~km}$ in length from east to west, and up to $800 \mathrm{~km}$ at its widest part, covering an area over $300,000 \mathrm{~km}^{2}$ in northern Xinjiang Autonomous Region. Gurbantunggut Desert, located in the hinterland of the Junggar Basin and with an area of $48,800 \mathrm{~km}^{2}$, is the second largest desert and the largest fixed and semifixed desert in China. Remote from the oceans and surrounded by high mountains, the area has a typical continental climate characterized by low precipitation, low specific humidity, long winters and short springs and autumns, ample sunshine and a wide temperature range. The region has an average annual precipitation of $200 \mathrm{~mm}$, and a high free surface evaporation of 1,400-1,700 $\mathrm{mm}$. The annual average temperature ranges from -4 to $9^{\circ} \mathrm{C}$ with mean temperatures of -20 to $-15^{\circ} \mathrm{C}$ and 22 to $26^{\circ} \mathrm{C}$ in January and July, respectively. The frost-free period in the study area is about 150 days per annum.

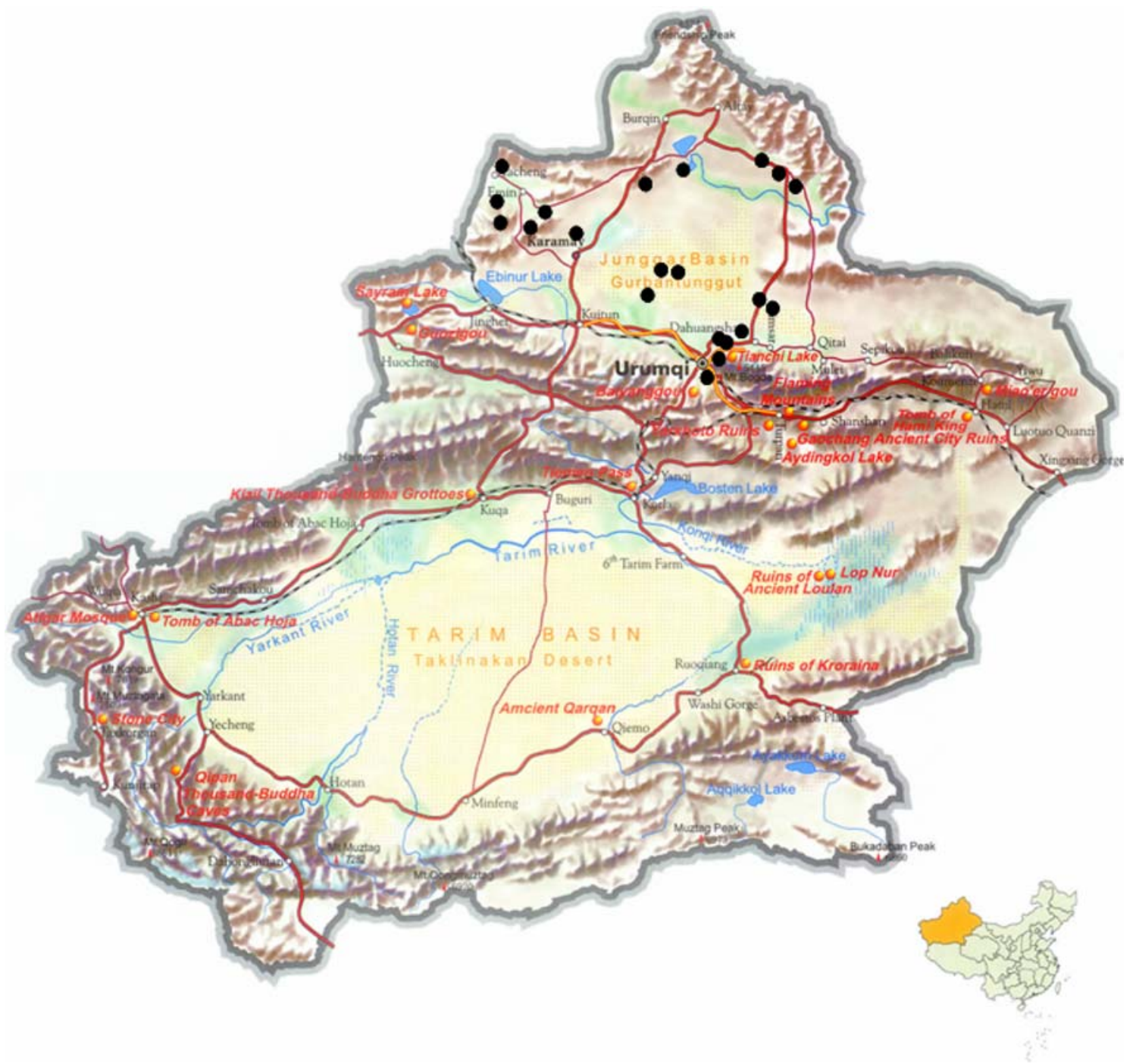

Fig. 1 Map showing the sampling sites in Junggar Basin, Xinjiang Autonomous Region, and northwest China. This map was downloaded from http://www.muztagh.com/map-of-china/large-map-xinjiang.htm 
Collection of soil and root samples

The locations of the sampling sites were determined using an eTrex C portable GPS [Garmin (Asia) Corporation, Taiwan] and are shown on the relief map of Xinjiang in Fig. 1. The top ca. 1-2 cm of the soil surface was removed and soil and root samples were collected. Care was taken during collection of individual plants that the roots could be positively identified as belonging to a particular plant. The entire plants were dug out by trowel to ensure that the roots remained connected to the shoots after sample collection. Samples were taken to the laboratory for determination of AM root colonization. Soil samples (ca. 1,000 g) associated with the plants removed were collected. The soil samples were air-dried before extraction, counting, and identification of AM fungal spores.
Assessment of AM colonization

Fresh roots (ca. $0.2 \mathrm{~g}$ ) were washed free of soil and cleared in $10 \%(\mathrm{w} / \mathrm{v}) \mathrm{KOH}$ at $90^{\circ} \mathrm{C}$ in a water bath for $20-30 \mathrm{~min}$, the exact time depending on the degree of lignification of the roots and their pigmentation. The root subsamples were cooled, washed, and cut into 0.5 to $1.0-\mathrm{cm}-\mathrm{long}$ segments and stained with $0.5 \%(\mathrm{w} / \mathrm{v})$ acid fuchsin (Biermann and Linderman 1981). Fifty root fragments (ca. $1 \mathrm{~cm}$ long) were mounted on slides in polyvinyl alcohol-lactic acidglycerol (Koske and Tessier 1983) and examined at $\times 100$ 400 magnification using an Olympus BX50 microscope equipped with an automatic photomicrographic system for the presence of AM fungal structures. The proportion of root length colonized was calculated according to the method of Trouvelot et al. (1986). If at least one root

Table 1 Fungal colonization of roots of spring ephemerals showing mean percentage colonization of root length with standard errors

\begin{tabular}{|c|c|c|}
\hline Family & Life form & Species, percentage of colonization, species with hyphae only and therefore of uncertain AM status (?) \\
\hline Liliaceae & $\mathrm{P}$ & $\begin{array}{l}\text { Allium setifolium: } 12 \pm 2(?) \text {; Eremurus inderiensis: } 35 \pm 8 ; \text { Gagea alberti: } 23 \pm 5 ; \text { G. bulbifera: } 28 \pm 3 \text {; } \\
\text { G. divaricata: } 22 \pm 3 ; \text { G. fedtschenkoana: } 14 \pm 2 ; \text { G. granulosa: } 22 \pm 8 ; \text { G. sacculifera: } 33 \pm 8 ; \text { G. stepposa; } 24 \pm 8 \text {; } \\
\text { G. tenera: } 68 \pm 9 ; \text { Tulipa iliensis: } 33 \pm 9 ; \text { T. schrenkii: } 35 \pm 7\end{array}$ \\
\hline Primulaceae & $\mathrm{P}$ & Androsace septentrionalis: $42 \pm 6$ \\
\hline Plantaginaceae & A & Plantago minuta: $55 \pm 8$ \\
\hline Labiatae & A & Eremostachys molucelloides: $59 \pm 10$; Nepeta micrantha: $40 \pm 35$; N. ucranica: $12 \pm 2$ \\
\hline Euphorbiaceae & A & Chrozophora sabulosa: $21 \pm 5$; Euphorbia pilosa: $72 \pm 2$; E. turkestanica: $22 \pm 5$ \\
\hline \multirow[t]{2}{*}{ Fabaceae } & A & $\begin{array}{l}\text { Astragalus ammophilus: } 16 \pm 4 ; \text { A. arpilobus: } 18 \pm 3 ; \text { A. oxyglottis: } 31 \pm 7 ; \text { A. stalinskyi: } 26 \pm 3 \text {; } \\
\quad \text { Trigonella arcuata: } 26 \pm 6\end{array}$ \\
\hline & $\mathrm{P}$ & A. lithophilus: $16 \pm 1$ \\
\hline Gramineae & $\begin{array}{l}\text { A } \\
P\end{array}$ & $\begin{array}{l}\text { Bromus tectorum: } 39 \pm 4 \text {; Eremopyrum orientale: } 33 \pm 6 ; \text { E. triticeum: } 24 \pm 9 ; \text { Schismus arabicus: } 29 \pm 6 \\
\text { Poa bulbosa: } 16 \pm 3\end{array}$ \\
\hline Zygophyllaceae & A & Zygophyllum lehmannianum: $17 \pm 3$ \\
\hline \multirow[t]{2}{*}{ Compositae } & A & $\begin{array}{l}\text { Amberboa turanica: } 16 \pm 2 \text {; Crepis tectorum: } 18 \pm 2 \text {; Heteracia szovitsii: } 9 \pm 4 \text {; Koelpinia linearis: } 52 \pm 8 \text {; } \\
\text { Lactuca altaica: } 54 \pm 4 \text {; Senecio subdentatus: } 31 \pm 5\end{array}$ \\
\hline & $\mathrm{P}$ & $\begin{array}{l}\text { Cancrinia chrysocephala: } 17 \pm 1 ; \text { C. discoidea: } 25 \pm 4 \text {; Echinops sphaerocephalus: } 35 \pm 8 ; \\
\text { Scorzonera circumflexa: } 28 \pm 8 ; \text { S. pusilla: } 45 \pm 17 \text {; Tragopogon kasahstanicus: } 43 \pm 11 ; \text { T. elongates: } 10 \pm 1\end{array}$ \\
\hline Chenopodiaceae & A & Atriplex dimorphostegia: $14 \pm 2(?) ;$ Corispermum lehmannianum: $33 \pm 10(?) ;$ Salsola praecox: $9 \pm 2(?)$ \\
\hline Ranunculaceae & A & Adonis sp.: 20(?); Ceratocephalus testiculatus: $18 \pm 4$ \\
\hline \multirow[t]{2}{*}{ Geraniaceae } & A & Erodium oxyrrhynchum: $30 \pm 6$ \\
\hline & $\mathrm{P}$ & Geranium transversale: $21 \pm 5$ \\
\hline Solanaceae & A & Hyoscyamus pusillus: $13 \pm 4(?)$ \\
\hline Umbelliferae & $\mathrm{P}$ & $\begin{array}{l}\text { Ferula dissecta: } 41 \pm 11 ; \text { F. ferulaeoides: } 60 \pm 19 ; \text { F. soongarica: } 35 \pm 8 ; \text { F. sp.1: } 53 \pm 16 ; \text { F. sp. } 2: 41 \pm 10 \text {; } \\
\quad \text { F. syreitschikowi: } 53 \pm 17 \text {; Soranthus meyeri: } 53 \pm 0\end{array}$ \\
\hline Cyperaceae & $\mathrm{P}$ & Carex physodes: $35 \pm 9$ \\
\hline Amaryllidaceae & $\mathrm{P}$ & Ixiolirion tataricum: $30 \pm 7$ \\
\hline Scrophulariaceae & A & Veronica campylopoda: $24 \pm 6$ \\
\hline \multirow[t]{2}{*}{ Papaveraceae } & A & Hypecoum parviflorum: $21 \pm 6(?)$ \\
\hline & $\mathrm{P}$ & Corydalis glaucescens: $23 \pm 7$ \\
\hline Iridaceae & $\mathrm{P}$ & Iris songarica: $19 \pm 4$ \\
\hline \multirow[t]{2}{*}{ Boraginaceae } & A & $\begin{array}{l}\text { Arnebia decumbens: } 13 \pm 1 \text {; Asperugo procumbens: } 27 \pm 14 \text {; Heliotropium acutiflorum: } 12 \pm 5(?) \text {; } \\
\text { Lappula spinocarpa: } 20 \pm 6 \text {; Lithospermum arvense: } 43 \pm 11 \text {; Nonea caspica: } 37 \pm 9 ;\end{array}$ \\
\hline & $\mathrm{P}$ & Arnebia sp.: 7 \\
\hline
\end{tabular}

$A$ Annual, $P$ Perennial

Plants with roots that contained hyphae but no coils/arbuscules or vesicles are shown as "?" and are only possibly mycorrhizal. Further information, with full binomials and authorities, percentage of root length with coils/arbuscules or vesicles, and spore densities in rhizosphere soil samples around roots of the individual plant species, are given as Electronic Supplementary Material on the Springer Website (http://www.springerlink.com) 
segment was observed to contain coils/arbuscules or vesicles, then the plant was recorded as an AM plant and denoted as "+". If the root cortex was found to be colonized by fungal mycelia without coils/arbuscules or vesicles, the plant was recorded as possibly AM and denoted as "?". The colonization data for specific structures are expressed as a percentage of root length.

Extraction and counting of AM fungal spores

The AM fungal spore numbers in the rhizosphere soil of 73 spring ephemerals were isolated and counted in a total 336 soil samples. Spores or sporocarps were extracted from 20-ml air-dried subsamples of each soil sample in triplicate by wet sieving followed by flotation-centrifugation in $50 \%$ sucrose (Dalpé 1993). The finest sieve used was $53 \mu \mathrm{m}$. The spores were collected on a grid patterned $(4 \times 4 \mathrm{~mm})$ filter paper, washed three times with distilled water to spread them evenly over the entire grid, and counted using a dissecting microscope at $\times 30$ magnification. A sporocarp was counted as one spore. The number of spores is expressed as the mean \pm standard error of three replicates. For observation and identification of spore characters, spores were mounted on glass slides in polyvinyl alcohollactoglycerol (PVLG) and PVLG + Melzer's reagent and then identified to species using current taxonomic criteria (Schenck and Perez 1990) and information published by INVAM on the internet (http://invam.caf.wvu.edu).

\section{Statistical analysis}

The data were analyzed using SPSS software version 11.0.

\section{Results}

The fungal colonization status of 73 species of spring ephemerals belonging to 20 families is summarized in Table 1. Further details are provided as "Electronic Supplementary Material" (http://www.springerlink.com). Fungi were found to colonize the roots of the majority of plant species examined. The overall mean colonization rate

Table 2 AM fungal genera identified and their times of spore presence and frequency of occurrence in soil associated with ephemeral plants

\begin{tabular}{lcl}
\hline $\begin{array}{l}\text { AM fungal } \\
\text { genus }\end{array}$ & $\begin{array}{l}\text { Times of spore } \\
\text { presence }\end{array}$ & $\begin{array}{l}\text { Frequency of occurrence } \\
(\%)\end{array}$ \\
\hline $\begin{array}{l}\text { Acaulospora } \\
\text { Archaeopora }\end{array}$ & 70 & 12 \\
Entrophospora & 6 & 2 \\
Glomus & 501 & 1 \\
Paraglomus & 13 & 83 \\
Scutellospora & 2 & 2 \\
Total & 603 & $<1$ \\
\hline
\end{tabular}

was $30 \%$ and ranged widely from 7 to $72 \%$. Coils/ arbuscules and vesicles were observed in 58 and 64 species with an average of 4 and 7\%, respectively (shown in the "Electronic Supplementary Material"). Coils/arbuscules were most abundant in the roots of Plantago minuta (Plantaginaceae) and vesicles in Androsace septentrionalis (Primulaceae). In summary, of the 73 spring ephemerals investigated, 89\% (65 species) formed AM. Another eight taxa $(11 \%$ of the total) contained fungal hyphae but not coils/arbuscules or vesicules. These were recorded as possibly AM. No plants were recorded as nonmycorrhizal. Among the plant species, one belonged to the Liliaceae, three to the Chenopodiaceae (a family often considered to be nonmycorrhizal or rarely AM), and the remaining four species belonged to the Ranunculaceae, Solanaceae, Papaveraceae, and Boraginaceae. Some of the ephemerals in families, traditionally considered to be nonmycorrhizal or rarely forming mycorrhizas, were colonized by AM fungi. For example, Carex physodes (Cyperaceae) was typically colonized (Table 1 ).

The AM fungal spore density varied from 0 to 120 , with a mean of 22 (shown in the "Electronic Supplementary Material"). Overall, 603 AM fungal spore (or sporocarp) samples belonging to six genera were obtained. Some spore types were identified to species according to their morphological characters but most of the specimens were identified to genus level because it was difficult to identify them to species owing to a lack of distinguishable fine taxonomic characters. As a result, the frequency of AM fungal occurrence was analyzed statistically only at the genus level. Glomus was the dominant genus, with a frequency of occurrence of $83.1 \%$ over all the spore samples examined (Table 2). The second genus in dominance was Acaulospora with a frequency of occurrence of $12 \%$. The frequencies of occurrence of members of the other four genera were very low (Table 2).

The proportion of root length colonized, the occurrence of coils/arbuscules and vesicles, and the spore densities of perennials were all slightly higher than those of annuals (Fig. 2). Coils/arbuscules or vesicles were observed in 18

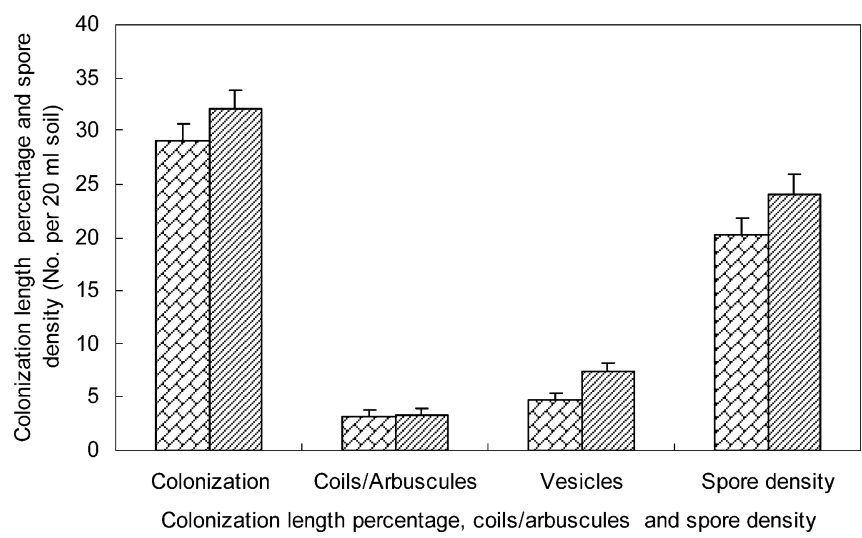

Fig. 2 Comparison of colonization status and spore density between annual and perennial spring ephemerals. Data are means and standard errors. " $G /$ : Annual species", “ $\mathbb{Z}$ : Perennial species" 
Fig. 3 Colonization status of different families of spring ephemeral plants " $\square$ : Colonization proportion", "B/: Coils/Arbuscules", " $\because \because$ Vesicles". Am Amaryllidaceae, Bo Boraginaceae,

Ch Chenopodiaceae, Co Compositae, $C y$ Cyperaceae, Eu Euphorbiaceae, $\mathrm{Fa}$ Fabaceae, Ge Geraniaceae, Gr Gramineae, Ir Iridaceae,

$\mathrm{La}$ Labiatae, $\mathrm{Li}$ Liliaceae, $\mathrm{Pa}$ Papaveraceae, $P l$ Plantaginaceae,

Pr Primulaceae, Ra Ranunculaceae, Sc Scrophulariaceae, So Solanaceae, Um Umbelliferae, Zy Zygophyl-

laceae. Data are means and standard errors

out of 20 families (Fig. 3). Plantaginaceae had the highest colonization (54\%) and occurrence of arbusucles $(20 \%)$. The lowest root colonization rate occurred in the Solanaceae (13\%) (Fig. 3). The highest spore densities were observed in the Plantaginaceae with 43 spores per $20 \mathrm{ml}$ air-dried soil and the lowest in the Euphorbiaceae, with only five spores per $20 \mathrm{ml}$ soil (Fig. 4).

\section{Discussion}

Trappe (1987) estimated that about $70 \%$ of angiosperms form arbuscular mycorrhizas, and most of these are herbaceous plants. AM fungi can play an important role in plant survival and in the community stability of vegetation in natural ecosystems (Gange et al. 1993; Francis and Read 1994; Azcón-Aguilar and Barea 1997; Hartnett and Wilson 2002; Moraes et al. 2004). Plant community structure and AM status and colonization might be used to monitor desertification and soil degradation. Several studies have been conducted in recent years on AM fungi in desert ecosystems (e.g., O'Connor et al. 2001; Titus et al. 2002; Collier et al. 2003; Ferrol et al. 2004).

Herbaceous ephemerals are widely distributed in many deserts and can grow well in very arid, infertile, and windy environments. They form important plant communities in the Jungggar Basin in early spring. About 196 individuals of Eremurus inderinsis, 135 of Erodium oxyrrhynchum, and 81 of Carex physodes were found per square meter in the Gurbantunggut Desert (unpublished data). Numerous studies have been reported on the functional significance, biological characteristics, and distribution of spring ephemerals (Mao and Zhang 1994; Li 2000; Zhang 2002a-c; Wang et al. 2003, 2004) but so far there is little information on the relationship between AM fungi and spring ephemerals. In the present study, hyphae but neither coils/arbuscules nor vesicles were observed in the roots of Atriplex dimorphostegia, Corispermum lemannianum, or Salsola praecox, which belong to the Chenopodiaceae. The occurrence of mycorrhizal colonization of species in the Chenopodiaceae has occasionally been reported (Allen 1983; Allen et al. 1989; Aguilera et al. 1998; O’Connor et al. 2001) although this family is usually thought to be nonmycorrhizal. Carex physodes (Cyperaceae), a species typically found at the top of sand dunes, was observed to form AM. Muthukumar et al. (2004) have pointed out that the number of plants in the Cyperaceae reported to form arbuscular mycorrhizas has been steadily increasing over a wide range of biomes including the savannas of Venezuela and China (Lovera and Cuenca 1996; Li et al. 2004) and Indian semiarid tropical grasslands (Muthukumar and Udaiyan 2002).

The higher colonization and spore densities of perennials than of annuals that we observed support the findings of Collier et al. (2003) in the Chihuahuan Desert and O'Connor et al. (2001) in the Simpson Desert, indicating that plants in stressed environments might rely on AM for survival. Colonization rates and spore densities also differed among the plant families. This may be attributed to a range of host plant characteristics including root morphology, genetics, and phenology (Baylis 1975; Lorgio et al. 1999; Eom et al. 2000).

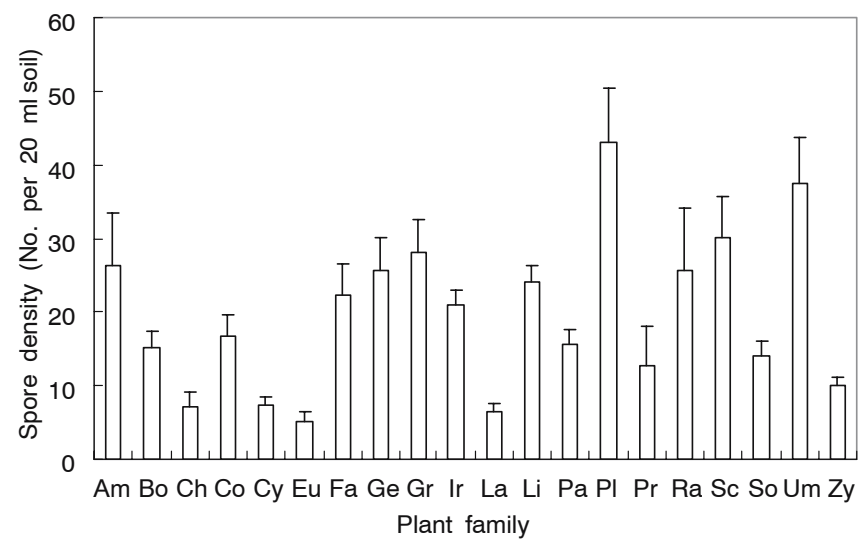

Fig. 4 Spore densities in different families of spring ephemerals. $\mathrm{Am}$ Amaryllidaceae, $\mathrm{Bo}$ Boraginaceae, $\mathrm{Ch}$ Chenopodiaceae, Co Compositae, Cy Cyperaceae, Eu Euphorbiaceae, $\mathrm{Fa}$ Fabaceae, Ge Geraniaceae, $G r$ Gramineae, Ir Iridaceae, $L a$ Labiatae, $L i$ Liliaceae, $\mathrm{Pa}$ Papaveraceae, $\mathrm{Pl}$ Plantaginaceae, $\mathrm{Pr}$ Primulaceae, $\mathrm{Ra}$ Ranunculaceae, Sc Scrophulariaceae, So Solanaceae, Um Umbelliferae, Zy Zygophyllaceae. Data are means and standard errors 
It has been reported that both spore production and species richness of AM fungi are lower in arid climates than in other ecosystems (Rose 1981; Pond et al. 1984), and decrease as aridity increases (Stahl and Christensen 1982; Stutz and Morton 1996). The mean spore density of 22 spores per $20 \mathrm{ml}$ of soil in our study was lower than reports from other ecosystems (Zhao et al. 2001; Li et al. 2004). However, our results are similar to those from other desert ecosystems such as the Mojave (Titus et al. 2002) and Negev (He et al. 2002) deserts.

AM fungi belonging to the genus Glomus seem to be dominant in the rhizosphere of spring ephemerals in Junggar Basin. This provides strong support for the conclusions of other workers that AM fungi belonging to Glomus tend to be dominant in arid ecosystems (Lamont 1982; Pande and Tarafdar 2004).

It is well known that AM fungi can increase plant nutrient uptake (Tarafdar and Praveen-Kumar 1996), water use efficiency (Augé and Stodola 1990) and resistance to abiotic stress under certain conditions. The association may therefore be expected to be especially important in desert ecosystems. Most plant families in arid regions have been found to form AM associations (Trappe 1981). Our results would seem to indicate that desert spring ephemerals may benefit from these associations. Why so many desert ephemeral plant species that finish their life span (even if only aboveground) in such short periods of time sacrifice their valuable carbohydrates to the associated fungi and how the AM fungi complete their life span during such a short time span are interesting questions. Changing the host plants via underground hyphal links may be an important mechanism as suggested by Lapointe and Molard (1997). However, unlike other ecosystems, few herbaceous plants survive in the sand dunes in summer in the Gurbantunggut Desert. The annuals die and the perennials enter a dormant period followed by senescence of aboveground tissues. Nevertheless, the roots of perennials could harbor AM fungi. The AM fungi must also germinate (presumably from spores) all at the same time and rapidly colonize the roots when spring arrives. The symbionts may depend on each other for survival in these extreme environments but further studies will be required to elucidate the mechanisms operating in desert ecosystems.

Acknowledgements The authors thank Professor Liyun Zhang for his valuable help in the identification of the plant species and the National Natural Science Foundation of China (Project 30470341) and Xinjiang Institute of Ecology and Geography, Chinese Academy of Sciences, for generous financial support.

\section{References}

Aguilera LE, Guteierrez JR, Moreno RJ (1998) Vesicular arbuscular mycorrhizae associated with saltbushes Atriplex spp. (Chenopodiaceae) in the Chilean arid zone. Rev Chil Hist Nat 71:291-302

Allen MF (1983) Formation of vesicular-arbuscular mycorrhizae in Atriplex gardneri (Chenopodiaceae): seasonal response in cold desert. Mycologia 75:773-776
Allen MF, Allen EB, Friese CF (1989) Responses of the nonmycotropic plant Salsola kali to invasion by vesiculararbuscular mycorrhizal fungi. New Phytol 111:45-49

Augé RM, Stodola JW (1990) An apparent increase in symplastic water contributes to greater turgor in mycorrhizal roots of droughted Rosa plants. New Phytol 115:285-295

Azcón-Aguilar C, Barea JM (1997) Applying mycorrhiza biotechnology to horticulture: significance and potentials. Scient Hort 68:1-24

Baylis GTS (1975) The magnolioid mycorrhiza and mycotrophy in root systems derived from it. In: Sanders FE, Mosse B, Tinker PB (eds) Endomycorrhizas. Academic, London, pp 373-389

Biermann B, Linderman RG (1981) Quantifying vesicular-arbuscular mycorrhizae: a proposed method towards standardization. New Phytol 87:63-67

Collier SC, Yarnes CT, Herman RP (2003) Mycorrhizal dependency of Chihuahuan Desert plants is influenced by life history strategy and root morphology. J Arid Environ 55:223-229

Dalpé Y (1993) Vesicular-arbuscular mycorrhiza. In: Carter MR (ed) Soil sampling and methods of analysis. Lewis Publishers, Boca Raton, FL, pp 287-301

Eom AH, David C, Hartnett A, Gail WT, Wilson C (2000) Host plant species effects on arbuscular mycorrhizal fungal communities in tallgrass prairie. Oecologia 122:435-444

Ferrol N, Calvente R, Cano C, Barea JM, Azcón-Aguilar C (2004) Analysing arbuscular mycorrhizal fungal diversity in shrubassociated resource islands from a desertification threatened semiarid Mediterranean ecosystem. Appl Soil Ecol 25:123-133

Francis R, Read DJ (1994) The contributions of mycorrhizal fungi to the determination of plant community structure. Plant Soil 159:11-25

Gange AC, Brown VK, Sinclair GS (1993) Vesicular-arbuscular mycorrhizal fungi: a determinant of plant community structure in early succession. Funct Ecol 7:616-622

Hartnett DC, Wilson GWT (2002) The role of mycorrhizas in plant community structure and dynamics: lessons from grasslands. Plant Soil 244:319-331

He XL, Mouratov S, Steinberger Y (2002) Temporal and spatial dynamics of vesicular-arbuscular mycorrhizal fungi under the canopy of Zygophyllum dumosum Boiss. in the Negev Desert. J Arid Environ 52:379-387

Jasper DA, Abbot LK, Robson AD (1991) The effect of soil disturbance on vesicular-arbuscular mycorrhizal fungi in soils from different vegetation types. New Phytol 118:471-476

Kennedy AC, Smith KL (1995) Soil microbial diversity and the sustainability of agricultural soils. Plant Soil 170:75-86

Koske RE, Tessier B (1983) A convenient, permanent slide mounting medium. Mycol Soc Am Newsl 34:59

Lamont B (1982) Mechanisms for enhancing nutrient uptake in plants, with particular reference to Mediterranean South Africa and Western Australia. Bot Rev 48:597-689

Lapointe L, Molard J (1997) Costs and benefits of mycorrhizal infection in a spring ephemeral, Erythronium americanum. New Phytol 135:491-500

Li XY (2000) Preliminary studying the characteristic of roots and relations between roots and environment of spring ephemerals in Xinjiang. Arid Zone Res 17:28-34 (in Chinese)

Li T, Li JP, Zhao ZW (2004) Arbuscular mycorrhizas in a valleytype savanna in southwest China. Mycorrhiza 14:323-327

Lorgio EA, Julio RG, Peter LM (1999) Variation in soil microorganisms and nutrients underneath and outside the canopy of Adesmia bedwellii (Papilionaceae) shrubs in arid coastal Chile following drought and above average rainfall. $\mathrm{J}$ Arid Environ 42:61-70

Lovera M, Cuenca G (1996) Arbuscular mycorrhizal infection in Cyperaceae and Gramineae from natural, disturbed and restored savannas in La Gran Sabana, Venezuela. Mycorrhiza 6:111-118

Mao ZM, Zhang DM (1994) Conspectus of ephemeral flora in northern Xinjiang. Arid Zone Res 11:1-26 (in Chinese) 
Moraes RM, De Andrade Z, Bedir E, Franck E Dayanc, Lata H, Khana I, Ana MS Pereira (2004) Arbuscular mycorrhiza improves acclimatization and increases lignan content of micropropagated mayapple (Podophyllum peltatum L.). Plant Sci 166:23-29

Muthukumar T, Udaiyan K (2002) Seasonality of vesiculararbuscular mycorrhizae in sedges in a semi-arid tropical grassland. Acta Oecol 23:337-347

Muthukumar T, Udaiyan K, Shanmughavel P (2004) Mycorrhiza in sedges — an overview. Mycorrhiza 14:65-77

O'Connor PJ, Smith SE, Smith FA (2001) Arbuscular mycorrhizal associations in the Simpson Desert. Aust J Bot 49:493-499

Pande M, Tarafdar JC (2004) Arbuscular mycorrhizal fungal diversity in neem-based agroforestry systems in Rajasthan. Appl Soil Ecol 26:233-241

Pond EC, Menge JA, Jarrell WM (1984) Improved growth of tomato in salinized soil by vesicular-arbuscular mycorrhizaal fungi collected from saline soils. Mycologia 76:74-84

Requena N, Pérez-Solis E, Azcón-Aguilar C, Jeffries P, Barea JM (2001) Management of indigenous plant-microbe symbioses aids restoration of desertified ecosystems. Appl Environ Microbiol 67:495-498

Rose SL (1981) Vesicular-arbuscular endomycorrhizal associations of some desert plants of Baja California. Can J Bot 59: $1056-1060$

Schenck NC, Perez Y (1990) Manual for the identification of vesicular-arbuscular mycorrhizal fungi. INVAM, Univ of Florida, Gainesville, FL, USA

Schüßler A, Schwarzott D, Walker C (2001) A new fungal phylum, the Glomeromycota: phylogeny and evolution. Mycol Res 105:1413-1421

Stahl PD, Christensen M (1982) Mycorrhizal fungi associated with Agropyron and Bouteloua in Wyoming sagebrush-grasslands. Mycologia 74:877-885

Stutz J, Morton JB (1996) Successive pot cultures reveal high species richness of indigenous arbuscular endomycorrhizal fungi in arid ecosystems. Can J Bot 74:1883-1889
Tarafdar JC, Praveen-Kumar (1996) The role of vesicular arbuscular mycorrhizal fungi on crop, tree and grasses grown in an arid environment. J Arid Environ 34:197-203

Titus JH, Titus PJ, Nowak RS, Smith SD (2002) Arbuscular mycorrhizae of Mojave Desert plants. West N Am Nat 62:327-334

Trappe JM (1981) Mycorrhizae and productivity of arid and semiarid rangelands. In: Manassah JM, Briskey EJ (eds) Advances in food-producing systems for arid and semiarid lands. Academic, New York, pp 581-600

Trappe JM (1987) Phylogenetic and ecologic aspects of mycotrophy in the angiosperms from an evolutionary standpoint. In: Safir GR (ed) Ecophysiology of VA mycorrhizal plants. CRC, Boca Raton, FL, pp 5-26

Trouvelot A, Kough JL, Gianinazzi-Pearson V (1986) Mesure du taux de mycorhization VA d'un systeme radiculaire. Recherche de methodes d'estimation ayant une signification functionnelle. In: Gianinazzi-Pearson V, Gianinazzi S (eds) Physiological and genetic aspects of mycorrhizae. INRA, Paris, pp 217-221

Wang XQ, Jiang J, Lei JQ, Zhang WM, Qian YB (2003) The distribution of ephemeral vegetation on the longitudinal dune surface and its stabilization significance in the Gurbantunggut Desert. Acta Geogr Sin 58:598-605 (in Chinese)

Wang XQ, Jiang J, Lei JQ, Zhao CJ (2004) Relationship between spring ephemeral plants distribution and soil moisture on longitudinal dune surface in Gurbantunggut desert. Chin J Appl Ecol 15:556-560 (in Chinese)

Zhang LY (2002a). Ephemeral plants in Xinjiang (I): eco-biological characteristics. J Plant 1:2-6 (in Chinese)

Zhang LY (2002b) Ephemeral plants in Xinjiang (II): diversity and ecological distribution. J Plant 2:4-5 (in Chinese)

Zhang LY (2002c) Ephemeral plants in Xinjiang (III): significance of community and resources. J Plant 3:4-5 (in Chinese)

Zhao ZW, Xia YM, Qin XZ, Li XW, Cheng LZ, Sha T, Wang GH (2001) Arbuscular mycorrhizal status of plants and the spore density of arbuscular mycorrhizal fungi in the tropical rain forest of Xishuangbanna, southwest China. Mycorrhiza $11: 159-162$ 


\section{Electronic supplementary material (www.springerlink.com)}

Fungal colonization of spring ephemerals (73 plant species in 20 families) and spore densities of AM fungi in rhizosphere soil samples. A: Annual; P: Perennial; C: Proportion of root length colonized; CA: Coils/Arbuscules; V: Vesicles; SD: Spore densities of AM fungi per $20 \mathrm{ml}$ soil; M: AM status, + AM formed, ? possible AM formation. Data are means and standard errors.

\begin{tabular}{|c|c|c|c|c|c|c|}
\hline Spring ephemeral plants & $\begin{array}{l}\text { Life } \\
\text { form }\end{array}$ & $\mathrm{C}(\%)$ & $\mathrm{CA}(\%)$ & $\mathrm{V}(\%)$ & $\mathrm{M}$ & SD \\
\hline \multicolumn{7}{|l|}{ Liliaceae (12) } \\
\hline Allium setifolium Schrenk & $\mathrm{P}$ & $12 \pm 2$ & 0 & 0 & $?$ & $4 \pm 1$ \\
\hline Eremurus inderiensis Regel & $\mathrm{P}$ & $35 \pm 8$ & $<1$ & $3 \pm 1$ & + & $8 \pm 1$ \\
\hline Gagea alberti Regel & $\mathrm{P}$ & $23 \pm 5$ & $5 \pm 2$ & $7 \pm 1$ & + & $23 \pm 3$ \\
\hline G. bulbifera Salisb. & $\mathrm{P}$ & $28 \pm 3$ & $1 \pm 1$ & $8 \pm 4$ & + & $36 \pm 14$ \\
\hline G. divaricata Regel & $\mathrm{P}$ & $22 \pm 3$ & $2 \pm 1$ & $7 \pm 2$ & + & $8 \pm 1$ \\
\hline G. fedtschenkoana Pasch. & $\mathrm{P}$ & $14 \pm 2$ & $3 \pm 3$ & $2 \pm 2$ & + & $39 \pm 3$ \\
\hline G. granulosa Turcz. & $\mathrm{P}$ & $22 \pm 8$ & $7 \pm 0$ & $7 \pm 1$ & + & $43 \pm 7$ \\
\hline G. sacculifera Regel & $\mathrm{P}$ & $33 \pm 8$ & $3 \pm 2$ & $12 \pm 3$ & + & $38 \pm 8$ \\
\hline G. stepposa Shue & $\mathrm{P}$ & $24 \pm 8$ & $7 \pm 3$ & $10 \pm 1$ & + & $26 \pm 3$ \\
\hline G. tenera Pasch. & $\mathrm{P}$ & $68 \pm 9$ & $10 \pm 10$ & $30 \pm 9$ & + & $37 \pm 6$ \\
\hline Tulipa iliensis Regel & $\mathrm{P}$ & $33 \pm 9$ & $4 \pm 3$ & $12 \pm 5$ & + & $20 \pm 4$ \\
\hline T. schrenkii Regel & $\mathrm{P}$ & $35 \pm 7$ & $5 \pm 4$ & $11 \pm 4$ & + & $22 \pm 7$ \\
\hline \multicolumn{7}{|l|}{ Primulaceae (1) } \\
\hline Androsace septentrionalis L. & $\mathrm{P}$ & $42 \pm 6$ & $15 \pm 15$ & $33 \pm 18$ & + & $13 \pm 5$ \\
\hline \multicolumn{7}{|l|}{ Plantaginaceae (1) } \\
\hline Plantago minuta Pall. & $\mathrm{A}$ & $55 \pm 8$ & $20 \pm 5$ & $16 \pm 4$ & + & $43 \pm 7$ \\
\hline \multicolumn{7}{|l|}{ Labiatae (3) } \\
\hline Eremostachys molucelloides Bunge & A & $59 \pm 10$ & $3 \pm 12$ & $12 \pm 1$ & + & $8 \pm 2$ \\
\hline Nepeta micrantha Bunge & A & $40 \pm 35$ & $3 \pm 3$ & $4 \pm 3$ & + & $3 \pm 1$ \\
\hline N. ucranica L. & A & $12 \pm 2$ & $5 \pm 2$ & $5 \pm 1$ & + & $7 \pm 1$ \\
\hline \multicolumn{7}{|l|}{ Euphorbiaceae (3) } \\
\hline Chrozophora sabulosa Kar. \& Kir. & A & $21 \pm 5$ & $4 \pm 4$ & $7 \pm 5$ & + & $3 \pm 2$ \\
\hline Euphorbia pilosa L. & A & $72 \pm 2$ & $6 \pm 3$ & $10 \pm 1$ & + & $6 \pm 3$ \\
\hline E. turkestanica Regel & A & $22 \pm 5$ & $3 \pm 3$ & $4 \pm 4$ & + & $6 \pm 1$ \\
\hline Fabaceae (6) & & & & & & \\
\hline
\end{tabular}




\begin{tabular}{|c|c|c|c|c|c|c|}
\hline Astragalus ammophilus Kar. \& Kir. & $\mathrm{A}$ & $16 \pm 4$ & $7 \pm 4$ & $7 \pm 6$ & + & $16 \pm 8$ \\
\hline A. arpilobus Kar. \& Kir. & A & $18 \pm 3$ & $4 \pm 4$ & $4 \pm 3$ & + & $4 \pm 1$ \\
\hline A. lithophilus Kar. \& Kir. & $\mathrm{P}$ & $16 \pm 1$ & 0 & $5 \pm 3$ & + & $7 \pm 1$ \\
\hline A. oxyglottis Stev. & A & $31 \pm 7$ & $2 \pm 1$ & $5 \pm 2$ & + & $3 \pm 1$ \\
\hline A. stalinskyi Sirjaev & A & $26 \pm 3$ & $3 \pm 2$ & $4 \pm 2$ & + & $2 \pm 1$ \\
\hline Trigonella arcuata C. A. Mey. & $\mathrm{A}$ & $26 \pm 6$ & $3 \pm 1$ & $6 \pm 2$ & + & $38 \pm 7$ \\
\hline \multicolumn{7}{|l|}{ Gramineae (5) } \\
\hline Bromus tectorum L. & $\mathrm{A}$ & $39 \pm 4$ & $6 \pm 4$ & $8 \pm 4$ & + & $24 \pm 2$ \\
\hline Eremopyrum orientale Jaub. \& Spach & A & $33 \pm 6$ & $<1$ & $2 \pm 1$ & + & $35 \pm 9$ \\
\hline E. $m$ triticeum (Gaertn.) Nevski & A & $24 \pm 9$ & $<1$ & $<1$ & + & $30 \pm 16$ \\
\hline Poa bulbosa L. & $\mathrm{P}$ & $16 \pm 3$ & $2 \pm 2$ & $3 \pm 1$ & + & $28 \pm 9$ \\
\hline Schismus arabicus Nees & $\mathrm{A}$ & $29 \pm 6$ & $<1$ & $3 \pm 2$ & + & $16 \pm 2$ \\
\hline \multicolumn{7}{|l|}{ Zygophyllaceae (1) } \\
\hline Zygophyllum lehmannianum Bunge & A & $17 \pm 3$ & $3 \pm 3$ & $6 \pm 3$ & + & $10 \pm 1$ \\
\hline Compositae (13) & & & & & + & \\
\hline Amberboa turanica Iljin & A & $16 \pm 2$ & $4 \pm 2$ & $2 \pm 1$ & + & $19 \pm 2$ \\
\hline Cancrinia chrysocephala Kar. \& Kir. & $\mathrm{P}$ & $17 \pm 1$ & $3 \pm 3$ & $3 \pm 3$ & + & $8 \pm 1$ \\
\hline C. discoidea (Ledeb.) Poljak. & $\mathrm{P}$ & $25 \pm 4$ & $1 \pm 1$ & $3 \pm 2$ & + & $6 \pm 1$ \\
\hline Crepis tectorum L. & A & $18 \pm 2$ & $4 \pm 4$ & $5 \pm 5$ & + & $9 \pm 2$ \\
\hline Echinops sphaerocephalus L. & $\mathrm{P}$ & $35 \pm 8$ & $3 \pm 1$ & $6 \pm 2$ & + & $18 \pm 6$ \\
\hline Heteracia szovitsii Fisch. \& Mey. & A & $9 \pm 4$ & $2 \pm 2$ & $3 \pm 3$ & + & $4 \pm 3$ \\
\hline Koelpinia linearis Pall. & A & $52 \pm 8$ & 0 & $14 \pm 8$ & + & $6 \pm 1$ \\
\hline Lactuca altaica Fisch. \& C.A.Mey. & A & $54 \pm 4$ & 0 & $<1$ & + & $36 \pm 16$ \\
\hline Scorzonera circumflexa Krasch. et & $\mathrm{P}$ & $28 \pm 8$ & $9 \pm 1$ & $9 \pm 2$ & + & $19 \pm 4$ \\
\hline \multicolumn{7}{|l|}{ Lipsch. } \\
\hline S. pusilla Pall. & $\mathrm{P}$ & $45 \pm 17$ & $2 \pm 1$ & $7 \pm 3$ & + & $13 \pm 2$ \\
\hline Senecio subdentatus Ledeb. & A & $31 \pm 5$ & $<1$ & $2 \pm 1$ & + & $11 \pm 6$ \\
\hline Tragopogon kasahstanicus Nikitin & $\mathrm{P}$ & $43 \pm 11$ & $4 \pm 2$ & $8 \pm 3$ & + & $36 \pm 13$ \\
\hline T. elongatus Nikitin & $\mathrm{P}$ & $10 \pm 1$ & $4 \pm 1$ & $3 \pm 1$ & + & $8 \pm 2$ \\
\hline \multicolumn{7}{|l|}{ Chenopodiaceae (3) } \\
\hline Atriplex dimorphostegia Kar. \& Kir. & A & $14 \pm 2$ & 0 & 0 & $?$ & $14 \pm 3$ \\
\hline Corispermum lehmannianum Bunge & A & $33 \pm 10$ & 0 & 0 & $?$ & $4 \pm 2$ \\
\hline Salsola praecox Litv. & $\mathrm{A}$ & $9 \pm 2$ & 0 & 0 & $?$ & $3 \pm 1$ \\
\hline
\end{tabular}




\begin{tabular}{|c|c|c|c|c|c|c|}
\hline Ranunculaceae (2) & & & & & & \\
\hline Adonis sp. & A & 20 & 0 & 0 & $?$ & 9 \\
\hline Ceratocephalus testiculatus (Crantz) & A & $18 \pm 4$ & $<1$ & $1 \pm 1$ & + & $27 \pm 10$ \\
\hline Roth & & & & & & \\
\hline Geraniaceae (2) & & & & & & \\
\hline Erodium oxyrrhynchum $\mathrm{MB}$ & A & $30 \pm 6$ & $3.6 \pm 1.7$ & $4.5 \pm 2.7$ & + & $14.8 \pm 3.5$ \\
\hline Geranium transversale Vved. ex & $\mathrm{P}$ & $21 \pm 5$ & $1 \pm 1$ & $6 \pm 2$ & + & $41 \pm 8$ \\
\hline Pavlov & & & & & & \\
\hline Solanaceae (1) & & & & & & \\
\hline Hyoscyamus pusillus L. & A & $13 \pm 4$ & 0 & 0 & $?$ & $14 \pm 2$ \\
\hline Umbelliferae (7) & & & & & & \\
\hline Ferula dissecta Ledeb. & $\mathrm{P}$ & $41 \pm 11$ & $5 \pm 4$ & $5 \pm 1$ & + & $24 \pm 7$ \\
\hline F. ferulaeoides (STEUD.) Korovin & $\mathrm{P}$ & $60 \pm 19$ & $5 \pm 5$ & $16 \pm 9$ & + & $39 \pm 7$ \\
\hline F. soongarica Pall. ex Schult. & $\mathrm{P}$ & $35 \pm 8$ & $5 \pm 3$ & $9 \pm 1$ & + & $63 \pm 25$ \\
\hline F.sp.1 & $\mathrm{P}$ & $53 \pm 16$ & 0 & $12 \pm 8$ & + & $52 \pm 15$ \\
\hline F. sp.2 & $\mathrm{P}$ & $41 \pm 10$ & $5 \pm 5$ & $5 \pm 0$ & + & $46 \pm 16$ \\
\hline F. syreitschikowii Koso-Poljansky & $\mathrm{P}$ & $53 \pm 17$ & $2 \pm 1$ & $3 \pm 1$ & + & $13 \pm 1$ \\
\hline Soranthus meyeri Ledeb. & $\mathrm{P}$ & $53 \pm 0$ & 0 & $7 \pm 2$ & + & $18 \pm 2$ \\
\hline Cyperaceae (1) & & & & & & \\
\hline Carex physodes M.Bieb. & $\mathrm{P}$ & $35 \pm 9$ & 0 & $5 \pm 4$ & + & $7 \pm 1$ \\
\hline Amaryllidaceae (1) & & & & & & \\
\hline Ixiolirion tataricum Herb. & $\mathrm{P}$ & $30 \pm 7$ & $6 \pm 3$ & $7 \pm 3$ & + & $27 \pm 7$ \\
\hline Scrophulariaceae (1) & & & & & & \\
\hline Veronica campylopoda Boiss. & A & $24 \pm 6$ & $3 \pm 3$ & $8 \pm 4$ & + & $30 \pm 6$ \\
\hline Papaveraceae (2) & & & & & & \\
\hline Corydalis glaucescens Regel & $\mathrm{P}$ & $23 \pm 7$ & $7 \pm 2$ & $6 \pm 2$ & + & $12 \pm 5$ \\
\hline Hypecoum parviflorum Kar. \& Kir. & A & $21 \pm 6$ & 0 & 0 & $?$ & $17 \pm 2$ \\
\hline Iridaceae (1) & & & & & & \\
\hline Iris songarica Schrenk. & $\mathrm{P}$ & $19 \pm 4$ & $3 \pm 1$ & $7 \pm 2$ & + & $21 \pm 2$ \\
\hline Boraginaceae (7) & & & & & & \\
\hline Arnebia decumbens Coss. \& Kralik & A & $13 \pm 1$ & $2 \pm 1$ & $1 \pm 1$ & + & $14 \pm 4$ \\
\hline A. $s p$. & $\mathrm{P}$ & 7 & 1 & 0 & + & 6 \\
\hline Asperugo procumbens L. & $\mathrm{A}$ & $27 \pm 14$ & $4 \pm 2$ & $4 \pm 2$ & + & $22 \pm 11$ \\
\hline
\end{tabular}




\begin{tabular}{|c|c|c|c|c|c|c|}
\hline Heliotropium acutiflorum Kar. \& Kir. & A & $12 \pm 5$ & 0 & 0 & $?$ & $19 \pm 2$ \\
\hline Lappula spinocarpa Aschers. ex & A & $20 \pm 6$ & 0 & $4 \pm 3$ & + & $19 \pm 7$ \\
\hline \multicolumn{7}{|l|}{ Kuntze } \\
\hline Lithospermum arvense L. & A & $43 \pm 11$ & $<1$ & $5 \pm 2$ & + & $19 \pm 2$ \\
\hline Nonea caspica G. Don & A & $37 \pm 9$ & $6 \pm 4$ & $6 \pm 3$ & + & $8 \pm 2$ \\
\hline
\end{tabular}

